JOANNA ZASEMPA - LUBLIN

\title{
WYSTAWA W BIBLIOTECE UNIWERSYTECKIEJ KUL „BENEDYKTOWI XVI W HOLDZIE” 1 III - 4 IV 2013 R.
}

„Benedyktowi XVI w hołdzie - Biblioteka Uniwersytecka KUL” - to tytuł wystawy, której inauguracja miała miejsce 1 marca 2013 r. o godz. 14.00 na IV piętrze Biblioteki Uniwersyteckiej KUL przy ul. Chopina $27^{1}$. Wystawa dzieł Benedykta XVI oraz pamiątek związanych z Jego Osobą była wyrazem potrzeby serca: wdzięczności za duchowe, a także intelektualne bogactwo tego pontyfikatu. Prezentacja została zainspirowana decyzją Benedykta XVI o abdykacji. Na otwarcie wystawy przybyło wielu znakomitych gości na czele z Wielkim Kanclerzem KUL, ks. abpem Stanisławem Budzikiem i prorektorem KUL, o. prof. Andrzejem Derdziukiem OFMCap. Wśród obecnych byli też m.in. s. prof. J. Zdybicka, prof. S. Sawicki, ks. prof. S. Longosz, ks. prof. R. Dzwonkowki, ks. prof. A. Maryniarczyk, ks. prof. M. Szram, prof. J. Jeszke i ks. dr T. Pajurek.

Jako pierwsza głos zabrała Pani Dyrektor Biblioteki Uniwersyteckiej KUL, Barbara Zezula. W słowach wdzięczności za Osobę i twórczość Benedykta XVI podkreśliła, że pontyfikat przechodzi dziś do historii. Zwracając się do przybyłych gości, podziękowała zgromadzonym za obecność, w sposób szczególny zaś ks. prof. Krzysztofowi Góździowi i prof. Marzenie Góreckiej, redaktorom polskiej edycji Opera Omnia. Wyrazy wdzięczności zostały skierowane także do pomysłodawców i organizatorów wystawy: dr Anny Zmorzanki, mgr Krystyny Wawryszuk, całego zespołu pracowników Czytelni Ogólnej i Czytelni Teologiczno-Filozoficznej oraz innych pracowników Biblioteki Uniwersyteckiej KUL, którzy zaangażowali się w przygotowanie wystawy. Kończąc, pani Dyrektor poprosiła o zabranie kolejno głosu ks. abpa Stanisława Budzika, o. prof. Andrzeja Derdziuka oraz organizatorkę wystawy, dr Annę Zmorzankę.

Ks. abp S. Budzik wyraził swoją radość z tego, że zrodził się pomysł oddania hołdu w formie ekspozycji odchodzącemu Benedyktowi XVI. Zwrócił uwagę na

\footnotetext{
${ }^{1}$ Uroczystość otwarcia wystawy została omówiona w podobnym artykule na łamach „Przeglądu Uniwersyteckiego". Zob. J. Zasempa, Benedyktowi XVI w hołdzie - Biblioteka Uniwersytecka KUL, „Przegląd Uniwersytecki”, 1/2 (141-142) 2013, s. 11.
} 
symboliczne znaczenie daty otwarcia, podkreślając, że jest to pierwszy dzień sede vacante, kiedy to papież przestaje być wspominany w modlitwie eucharystycznej Kościoła. Podkreślił jednak, że: „Papież odszedł z urzędu, ale się nie oddalił. On dalej będzie przebywał w sercu Kościoła i będzie zajmował się tymi sprawami, które były dla Niego najważniejsze. Bo przecież głosił prymat Boga, prymat modlitwy, prymat Bożej obecności. Nadal jest w sercu Kościoła. Nadal jest w naszych sercach -nie tylko przez wspomnienie Jego krótkiego, ale jakże intensywnego i pięknego pontyfikatu, ale przede wszystkim przez znakomite dzieła, które tutaj w takiej obfitości są pokazane, zwłaszcza Jego «Dzieła zebrane», których wydawaniem Uniwersytet słusznie się szczyci”. Ks. Arcybiskup przypomniał też, że 1 marca 2013 roku minęło 25 lat od momentu, gdy Senat naszej Uczelni zatwierdził uchwałę Rady Wydziału Teologii o nadaniu tytułu Doktora Honoris Causa ks. kard. Prefektowi Kongregacji Wiary Józefowi Ratzingerowi.

Następnie ks. Arcybiskup poprowadził modlitwę „Ojcze nasz” w intencji Benedykta XVI oraz całego Kościoła, którą zakończył słowami: „Boże, wiekuisty Pasterzu, Ty nigdy nie opuszczasz swojej owczarni ani swoich apostołów, ale otaczasz ich nieustanną opieką, prosimy Cię, bądź przy Ojcu Świętym, Benedykcie XVI, emerytowanym Papieżu, umacniaj Go swoją łaską, spraw, by Jego modlitwa w sercu Kościoła i za Kościół przynosiła obfite owoce i łaski. Poślij Kościołowi swojego Ducha, strzeż Go od wszelkiego złego i daj Mu Pasterza na nowe trudne czasy, w których pełen Bożego Ducha będzie kontynuował to wielkie dziedzictwo papieży Jana Pawła II i Benedykta XVI. Prosimy Cię o to przez Chrystusa, Pana naszego. Amen". Po wspólnej modlitwie ks. Arcybiskup ogłosił wystawę za otwartą.

Z kolei o. prof. A. Derdziuk zaznaczył, że wydarzenie, w którym uczestniczymy, to nie tylko prezentacja dzieł Papieża, znajdujących się w zasobach Biblioteki, ale także próba pokazania myśli człowieka, który jest „gigantem ducha, niezmordowanym świadkiem prawdy, sługą naszej radości”. Podkreślił, że w obecnych czasach, pełnych irracjonalizmu, bardzo ważne jest przypominanie w jaki sposób o wierze pisał Benedykt XVI. „Sięganie do dorobku Papieża jest czymś, co uczy myśleć, jednocześnie Jego twórczość pokazuje, że nasza wiara jest oparta na bardzo twardych przesłankach, na objawieniu się Jezusa Chrystusa, wokół którego chcemy się koncentrować." - powiedział o. Prorektor. Na koniec stwierdził, że eksponowane na wystawie dzieła są zachętą do nowych badań nad pismami Papieża.

Dalszą część spotkania poprowadziła A. Zmorzanka, która zaprosiła obecnych do wysłuchania utworów przygotowanych przez dwoje młodych artystów: Andrzeja Gładysza, tenora i Deborę Kramarek, skrzypaczkę. A. Gładysz zaśpiewał hymn Veni Creator Spiritus. Wyjaśniając na wstępie swój wybór, powiedział, że pragnął, aby jego śpiew był dziękczynieniem za pontyfikat odchodzącego Benedykta XVI i modlitwą o światło Ducha Świętego dla Kolegium Kardynalskiego przed wyborem nowego papieża. Natomiast D. Kramarek zagrała Andante z II Sonaty na skrzypce solo Jana Sebastiana Bacha. Po występie artystów A. Zmorzanka powiedziała o genezie wystawy, której pomysł zrodził się spontanicznie w pierwszą sobotę po ogłoszeniu przez Papieża decyzji o abdykacji. Wyjaśniła, że 
dzięki niesamowitym zbiegom okoliczności na wystawę trafiły pamiątki z kolekcji prywatnych, dlatego też trzeba było ograniczyć ilość eksponowanych książek do najważniejszych pism Papieża. Ostatecznie na wystawę trafiły: pisma dokumentujące początki pontyfikatu oraz tzw. Biblia Benedykta, wydana z okazji 80tych urodzin Papieża przez wydawnictwo Herder (1. gablota), pisma papieskie: encykliki, adhortacje, listy, orędzia, katechezy, homilie, przemówienia okolicznościowe, medytacje i modlitwy (2. i 3. gablota), trzy z dotychczas wydanych tomów Opera Omnia, zdjęcia upamiętniające wręczenie XI tomu tego dzieła przez ks. prof. K. Góździa i prof. M. Górecką Ojcu Świętemu, a także różne wydania trylogii Jezus z Nazaretu (4. gablota), publikacje poświęcone pielgrzymce Ojca Świętego do Polski, listy do biskupów Polskich oraz zdjęcia prywatne, m. in. z uroczystości wręczenia paliusza ks. abpowi St. Budzikowi (5. gablota), osobiste pamiątki: monety, medale, kalendarze, zdjęcia z pielgrzymek (6. gablota), pisma Józefa Ratzingera (7. gablota), zdjęcia z nadanie ks. Kardynałowi Doktoratu Honoris Causa na Katolickim Uniwersytecie Lubelskim, kserokopia wpisu ks. kard. Józefa Ratzingera do Księgi Gości WMSD w Lublinie oraz kopia artykułu R. Korna Katolicka Alma Mater, opisujący tę uroczystość („Niedziela”, wyd. z 11 XII 1988 r.).

Na koniec A. Zmorzanka poprosiła uczestników, aby podzielili się osobistymi refleksjami związanymi z Benedyktem XVI. Jako pierwszy wypowiedział się ks. abp S. Budzik, który wspomniał o kilku spotkaniach z Ojcem Swiętym. Szczególną uwagę zwrócił na jedno. Miało ono miejsce podczas Roku Kapłańskiego, kiedy to wraz z innymi członkami Prezydium Episkopatu Polski gościł u Papieża. Stało się ono ważne - jak podkreślił - $z$ dwóch powodów. Po pierwsze, wręczył wtedy Papieżowi księgę zawierającą 3.000 imion polskich księży zamordowanych przez totalitaryzmy niemiecki i sowiecki, których symbolem stały się nazwiska ks. Maksymiliana Marii Kolbego i ks. Jerzego Popiełuszki. Po drugie, padło wówczas pytanie o kanonizację Jana Pawła II. Ks. Arcybiskup podkreślił, iż w obu przypadkach reakcja Benedykta XVI była bardzo życzliwa i spontaniczna, co wyrażało się w stwierdzeniu, że Polacy są narodem męczenników oraz w zapewnieniu o codziennej modlitwie w intencji kanonizacji Papieża Polaka.

Natomiast ks. Krzysztof Góźdź wspominał rozważania Papieża na temat, czym jest ewangelizacja: „Ewangelizować to znaczy odnaleźć drogę swojego życia, odnaleźć sztukę swojego życia”. Ks. Krzysztof Góźdź docenił to, że Benedykt XVI wskazywał na Chrystusa jako na tę drogę i zachęcał, abyśmy byli „tubą Boga, tubą Chrystusa”. A kroczenie tą drogą - jak powiedział - oznacza codzienne nawracanie się.

Na koniec goście zostali poproszeni o wpisywanie się do Księgi Pamiątkowej oraz do kontynuowania refleksji wysnutych z myśli Benedykta XVI przy herbacie i kawie w Czytelni Teologiczno-Filozoficznej.

W ciągu pierwszych dni trwania wystawy swoją obecnością i błogosławieństwem dla pracowników ubogacili bibliotekę Nuncjusz Apostolski w Polsce ks. abp Celestino Migliore, ks. bp Artur Miziński oraz Prodziekan Wydziału Teologii ks. prof. Janeczek, a także ks. prof. Stanisław Koczwara, wykładowca Wydziału Teologicznego w Wilnie. Wystawa była odwiedzana i oglądana przez wielu zainteresowanych codziennie do 4 kwietnia $2013 \mathrm{r}$. 